\title{
Enjoying Seven Days a Week
}

\author{
Puyu Zhang
}

\section{Interview with Miss Yijie Sun's Mother and Yijie Sun}

Yijie Sun, female, born in 1987. Only child. Grade IV intellectual disability. Graduated from the special school-Miyun School in Hongkou District, Shanghai.

Interviewee: Huifang Zhu (Yijie Sun's mother) and Yijie Sun

Presenter: The mother of Yijie Sun's classmate from the Sunshine Home

Interviewer and writer: Puyu Zhang

Interview dates: October 23 and December 10, 2016

Interview place: Hongkou District Disabled Persons' Federation, Shanghai.

\section{Poor Health, but Rich in Love}

Q: May I ask how you and Yijie's father first met?

Sun's mother: We met in 1984 through his younger brother who was my colleague. So, I had an opportunity to get to know my future husband when I visited my colleague's family. At that time, he lived in Anhui Provence-this was probably Fuyang City or somewhere close-he had gone to live in the countryside and settled in the commune. At that time, I worked on a state-owned farm. Later on, through the government's policy for educated young people, both of us returned to Shanghai and worked in a factory.

Q: When was Yijie born?

Sun's mother: She was born in September 1987. A normal pregnancy is 9 months, but mine was longer than that because the doctor said the fetus was very small and the best way to reduce risk was to let her spend a longer time in my body. So, I stayed in hospital and had extra nutrition through a drip every day. She was just above $4 \mathrm{lb}$ when she was born, but didn't have any other problems at that time. For a long time,

P. Zhang $(\varangle)$

East China Normal University, 3663 Zhongshan Bei Ro, Shanghai 200062, China 
being undersized was the main problem for her, even now, she is still the smallest in her group.

I gave birth when I was 32, quite old. At this age, the child was so precious to me and her condition worried me desperately. The only thing I could do was take her to see the doctors and she was given all kinds of tests. People were always surprised by her size when she was a baby; all of her body indexes were lower than average, she was always very weak physically. Anyway, children like her always have one kind of problem or another. Some children might develop well physically, but their IQ is another thing. My girl's main problem is her physical ability.

The doctor said she might be very difficult to bring up and there was a strong possibility that she might not develop into an independent person. The doctor's final diagnosis was the child wouldn't be easy to raise and might not live for very long.

I kept asking myself: "What could I do for her?" I thought, I gave her life, she must be my responsibility, so I just totally ignored what the doctor said. Sometimes, when I think about my daughter, it was really very hard to bring her up.

In her class, Yijie is always the first person to catch something; if anybody gets sick, it doesn't matter whether it's a cough or headache, she usually gets worse much quicker than the student who was sick in the first place. She also has problems with her teeth, which stop her from eating hard food: her front teeth are false. Actually, she has two fewer teeth than normal people, because those teeth didn't develop well, they never came out properly. When she was young, the dentist suggested reshaping her poor canine teeth, and taking one tooth out, but I just thought it's not necessary for a young girl, so I didn't take the dentist's advice.

In the beginning, I couldn't work out why she had such bad teeth, because she didn't eat snacks or do things that might damage her teeth. Actually, the problem stems from her poor physical quality. Finally, she had orthodontic surgery, it was self-financed medical treatment and the false teeth cost us over 10,000 yuan-that's 1,500 yuan for each tooth, and she needed five. At the same time, dental cavity treatment is very expensive as well, 5,000 yuan for one course. Maybe it's a genetic thing, because I have bad teeth too. I've been to the dentist's clinic for periodontitis this Wednesday, it's so painful. I worry about her because her teeth are bad enough at this age, what will they be like when she grows up? It's a real hopeless thing, now, at my age, I can't eat food properly anymore.

Q: What do you do about eating, then?

Sun's mother: The best thing I can have is congee, anything harder makes things worse; my teeth even hurt after eating the rice noodles I had at lunch time.

Q: Did Yijie go to a nursery when she was little?

Sun's mother: Yes, she went to a nursery. She did the right things at the right age like other children, nursery and primary school. Her nursery was an ordinary one in our area.

Q: Did everything go well when she was at school?

Sun's mother: When she was at the nursery, at a very young age, the teacher taught the children to be independent with some domestic things like eating, sleeping, getting up, getting dressed, and using the toilet, but my daughter couldn't do that; she was much slower than the other children. The teacher was very patient with her and gave 
her plenty of time to learn new things at her own pace, slowly but surely; from eating to dressing herself, to making her bed after a nap.

She didn't enjoy eating and we had to force her to eat. She was very picky with food and only ate things she liked and wouldn't try other things even if they were delicious. For example, lots of children really like soft drinks, but she wasn't interested in them at all. Anyway, eating was a difficult thing for her and sometimes she wouldn't eat for 3 days if I didn't force her. So, I tried my best to feed her until she was 18, then, and we were so pleased, she started to get a better appetite and became stronger.

After she graduated from the nursery, she passed the entrance exam for primary school without any problems. Then she fell behind in her studies, it got worse and worse for the first couple of years. She didn't have a real sense of time, she was very slow with her homework and never worried about deadlines. I'd monitor her home work each day and we always finished very late. In the beginning, she was left-handed (raises her left hand), it took her paternal grandma quite a lot of work to correct her. She couldn't write her own name properly either and I used to think why didn't I give her a less complicated name like "Yi" or "Ding?"1

The teacher was always concerned about the class's average score, so my daughter became a problem. The teacher kept contacting me to explain my daughter's situation. Before that I just thought she wasn't very good at her studies and was a slow learner, I never considered it might be an IQ problem. The Dean told me to take her for an intelligence test at the Maternity and Infant Hospital to see if her condition was more suited to a special school; if that was the case, she'd be better off at the district Special School, a non-competitive school where all students are treated equally. Then we did the test.

Q: Do you remember her intelligence test score?

Sun's mother: We did it twice and the scores were 63 and 65 . I asked what the results meant, and the doctors told us that the average score is 70. My daughter was slightly under the average, so her problem wasn't severe. But if she tried harder, she might reach the average score. At that time, she was around 10and in the second or third year of school and she was only little.

While she took the test, the parents had to wait outside, but when she came out, she told me she knew most of the answers and the questions were very basic, just about her address, parents' names, recognizing some animals.

The thing we didn't know was, if she had been diagnosed as a severely intellectually disabled child, she might have been eligible fora disabled allowance from the government when she became an adult; but mildly disabled children-like my daughter-don't receive any money. I'd heard that some parents who wanted their children to get this allowance prepared their children before the test and told them not to answer the doctor's questions. Their disability grade was decided by the hospital and doctor and not the special school, but we didn't know that. We thought her intellectual condition was determined by her behavior at the special school. That's how her disability grade was decided at that time.

\footnotetext{
${ }^{1}$ The Chinese character 'Yi' is written as '一', which means it has only one stroke; 'Ding' is written as '丁', with two strokes. Both of them are among the simplest of Chinese characters.
} 
Q: How did your husband and you feel when you found out about Yijie's condition?

Sun's mother: My feeling was... the truth was, I could have another child and I thought about this, but I was worried that I wouldn't be able to keep the right balance between the two children. If I had two children, Yijie, and a child without disability, I would be worried that the young one might become my favorite and Yijie's situation could become worse. For example, for my generation, almost all people come from a big family with several siblings, like my own family, where the parents usually have a favorite child. I was worried that I might become that kind of parent...Actually, compared to children without disability, my daughter certainly needs more attention. Finally, I made the difficult decision that we wouldn't have another child and I decided to give all my love to my daughter.

Some families in our situation chose to have a second child, but we decided if we did this it might not be fair to her. From time to time, I think about the future, but right now, we're focused on her happiness and her daily wellbeing; we've put the future to one side. That's how I feel.

Q: Did you start keeping her company all the time when you discovered her intellectual difficulties?

Sun's mother: Sure, we looked after her all the time from school age until now. On the one hand, she's a little girl; on the other, she still can't find her way around when she goes out alone. She's very different to Xiao Y who you met yesterday; his mother never worries about letting him go out by himself. My daughter always has to be under my supervision, because she can't find her way.

All her teachers and officials at the district Disabled Persons' Federation office said I spoil my daughter too much. I can't help it, as a parent I must love her as much as I can while we're still together. When we pass away, she might have to depend on her cousins - my sister and brother's children — but one day they'll have their own families as well. It won't be possible for her to depend on them.

\section{Loving Teachers Are Always with Her}

Q: When did Yijie go to the Special School?

Sun's mother: When she got the result of her intelligence test, she went to the Miyun Special School and joined the third-year class. There, they used different textbooks to the ordinary school and she had more time to learn. Basically, she was able to read and she was good at reading pinyin, but the problem was she couldn't do mental arithmetic without using a pen and paper.

The Special School has a 9-year program, so there isn't a middle school. During her school years, she grew up little by little and started doing things better and quicker until she graduated. It was so difficult for her growing up.

Q: Did you try anything to develop her intelligence?

Sun's mother: Even though it was a Special School, the teachers were very concerned about the students' studies. As parents, we always wanted her to learn as much as possible, at least to be able to read, understand pinyin, and have some basic math skills. We tried to help her with her studies, but it was very hard. She was a very slow learner. I tutored her at home until her sixth year and by that time she could 
already read. She had a very poor memory and was only able to remember words she used every day. Now, she only has very basic skills.

These days, I understand that parents have to make sure their children learn the right things at the right time, otherwise they might fall behind and never catch up. Even though my daughter can use a mobile for messaging and We Chat, but she wouldn't dare go shopping by herself, because she has never been told how to buy things and she doesn't have a sense of money. Money has no meaning for her and I worry she might not be able to go shopping on her own in the future. Some of her classmates are really good at shopping, but she's totally the opposite, we even have to buy her snacks.

Q: How many students were in her class when she was at Miyun School?

Sun's mother: Around 15 classmates, but they lost contact after they graduated; my daughter lost touch with her best friend when the girl moved somewhere else. There is one boy, years after they graduated, who now studies at the same Sunshine Home. Actually, at this Sunshine home, some of the students like my daughter came from the same school, they are very happy in each other's company.

Q: Were Chinese and math their main subjects at the Miyun Road School?

Sun's mother: Yes, they also had singing, PE, and dance classes, but they didn't have any complex subjects. Basically, their subjects were similar to an ordinary school, but they didn't have to worry about grades. These students have very different intellectual disabilities and they have to go in different ways after they graduate.

Q: What was Yijie's favorite subject?

Yijie Sun: I liked PE and singing...

Q: Did they have any school or class activities, for example, like spring or autumn picnics?

Sun's mother: They rarely had activities because the security of the students is the first concern of the school; but they arranged some activities taking this into account.

It was a heavy responsibility for the teacher when the students went out. I guess for those teachers, it's less trouble and easier when they don't have to take risks while the students are taking part in activities. Here, at the Sunshine Home they have spring and autumn picnics and from time to time, the volunteer companies invite them to do some events together, there is always something going on.

Sun: We have sports events as well.

Q: How about the relationship between Yijie and her teachers?

Sun's mother: She's a very lucky person, all her teachers at nursery and primary school were very nice. For the first 2 years at primary school, the teacher was concerned about her and complained to me quite often before she knew about my daughter's condition. The only thing I could do at that time was to tell the teacher the truth and buy her some gifts, because she looked after my daughter. The teacher never took those gifts, and still gave my daughter lots of attention. What else can we do?! Later she went to the Special School and she was taught by the same teacher until she graduated. She was lucky, because these kind teachers treated her as if they were their own children.

The Sunshine Home has some very nice teachers too; there are two of them who are particularly kind with the children. Actually, some parents think that they look 
after these children too well. I think the same and say to the teachers sometimes: "I understand you like these children very much, but they need stricter rules."

Q: Did she make some friends at the school?

Sun's mother: She had one very close friend. I met this girl several times and realized she was a very smart girl, always at the top of all kinds of things, except for her studies. The girl had a twin sister who was a very fast learner. This girl got a job with a teacher's reference after she graduated as a dish cleaner at the Xinya Restaurant - a western restaurant under the bridge of North Sichuan Road. She's really great and skillful.

Sun: She's very big, very fat.

Sun's mother: She's the same age as my daughter.

Sun: She was "the squadron leader" at school.

Sun's mother: She sounds like a really mature child. Once she said to me: "This work is too hard for Yijie, she wouldn't last a week if she was here. Even I had to try my best to keep the job." Every child has his/her own characteristics, even though all of them are intellectually disabled.

My daughter certainly couldn't do this job, on the one hand I wouldn't let her do it; on the other, she doesn't have the ability, she isn't suited. That girl has very strong motivation, the same as people without disability: "I have to work, I have to make money, I have to be determined and I don't care about gossips." In the work place, there are some good people for sure, but that doesn't mean everybody has enough patience with a new worker who has a disability. This girl is wonderful, but my Yijie couldn't do a job like that.

Q: What did you like to play with when you were a child?

Sun's mother: (She asks her daughter with a smile) can you tell us what you liked? Sun: Playing with the computer.

\section{Heavy Work Isn't for a Weak Person}

Q: Where did Yijie go when she graduated?

Sun's mother: She took a 2-year vocational course afterwards. She learnt computer skills, hotel servicing, and flower arranging and something else there. My daughter is very small, she can't deal with heavy work at the hotel and even her teacher said hotel work is too much to her. After that, she spent 2 years, more or else, at home.

Q: What did she usually do when she was at home?

Sun's mother: She liked to play on the computer. I was working, so I didn't have enough time and attention for her. I just let her do things she liked to do; this was the only thing I could do. By the way, could you tell my daughter's age? She's 30!

Q: No, I couldn't tell that at all, because she looks so young.

Sun's mother: That's right; she's a very small girl as well. Employers never want to hire her if she goes for job interviews against people without disability. We stopped looking for a job for her after she had been rejected by employers several times; people always say "no" to my daughter. The real world can be very cruel. After she was rejected several times, I lost my confidence and gave up trying to find her a job. Anyway, I just let her stay at home. 
There are several children like her who are working, you can tell they're different from other people by their faces, but they have been very good workers at the supermarket for years. They've been working in the old supermarket for over 7 or 8 years. They're well behaved, conscientious workers and always follow their supervisors' orders.

They're very obedient children, but don't know how to deal with criticism from supervisors or colleagues, they just bottle up their feelings. When they come back home, their unknowing parents might not understand the reason for their children's miserable behavior and this could make things worse.

There's a strong boy, a neighbor's son, who's a shelf stocker at a small Xinhua bookstore nearby. That's a heavy job only for strong people like him; the books are small but very heavy. I can't image Yijie doing this job! Now I don't want her to find a job anymore, I'm just going to let her stay with me.

People tell me my daughter is able to work, but I'm not convinced that she'd be successful. I would never feel at ease if she went to work, I really can't let her do that. She stays with me all the time, everywhere. I know this isn't great, it might be a bit selfish, because I should let her get a job and become independent. It's a just commonsense. My mind won't be at rest if she goes out to work. If she could talk about herself better, for example about what has happened during her day, what the supervisor said, then I'd be more confident about letting her work. The truth is, I can never know what she does in the workplace every day, because she can't answer my questions properly. Anyway, she can't look after herself outside.

I don't feel bad anymore; I just try my best to look after her until one day I can't do it anymore. I guess the government might need to look after them then. Compared to the past, I don't have anything to complain about, even though some people ask for more help from the authorities, but I don't (she's laughing).

\section{Be Happy Every Day}

Q: Why did you send her to the district DPF's activities, especially the Sunshine Home?

Sun's mother: I found out about the DPF office and the Sunshine Home very late, because I was always moving between work and home before I retired, I didn't know about the subdistrict office either. Until one day, Teacher Feng, a disabled persons' assistant, came to me and told me about the institute and its weekly activities. $\mathrm{He}$ said I should let my daughter try it and I thought it might be a very good thing for her. Actually, by then, I had completely accepted having a disabled daughter. I didn't want to hide her away, so I asked around to find something for her to do. These days, I've got a much better knowledge about the related institutes and their activities and make sure my daughter can join as many as she wants. Since then, some parents and I have become good friends during the children's practice and events.

Teacher Feng said he has a very deep sense of how my daughter has changed since he visited for the first time. Yijie didn't have any social skills and didn't want to talk to him at all. Now she is a totally different person. 
The home has a very busy schedule for the children, the volunteers teach them very difficult Bel-Canto every Monday morning, on the same afternoon, another teacher comes to teach them piano and read music.

Sun: At the Sunshine Home, Teacher Zhou teaches us Bel-Cantoon Monday morning, and in the afternoon is music class. Last time the teacher taught us "Country," sign language "Country."

Q: What kind of songs do you like?

Sun: Pop songs. I love A-du, ${ }^{2}$ Yasen Chen's My Happiness Is Thinking of You. I liked Wenjun Man's Understanding You a long time ago, but I don't like him anymore.

Q: What's your favorite new song?

Sun: I listen to pop music all the time, songs about Tibet and Inner Mongolia. I like To Wander and The Love Story of Western Sea by Jamyang Dolma, ${ }^{3}$ she sings both of them.

Sun's mother: She likes to go to the karaoke hall with her teacher.

Sun: We sing all kinds of songs, including English songs and Yue Opera. I like to sing The Angel Arrives in the World ${ }^{4}$ from Yue Opera, Shanghai Opera's Open a Window for You, ${ }^{5}$ Returning from the Target Shooting Exercise, Songs and Smiles, My Motherland, Today Is Your Birthday, We Are Good Friends, and Joy Division.

Sun's mother: What do you do on Tuesdays?

Sun: English.

Sun's mother: They have a volunteer teacher, a foreign boy, to teach them English. They only study some very basic things, but he gives everybody an English name. There's another volunteer who comes on Wednesdays to teach them to dance.

Q: Do you dance at home?

Sun: I rarely do, I only dance at the Sunshine Home.

Sun's mother: She plays with her mobile all the time, she can't survive without that phone.

Q: How long does it take you to learn a new dance?

Sun: We have to practice it for a long, long time.

Sun's mother: The dance Sparkling Red Star which you saw last time. This teacher comes once every week, but after 2 months of study they haven't finished yet.

$\mathrm{Q}$ : The teacher choreographs the dance as well?

Sun's mother: The dance teacher, a mother of one of the students, choreographs a part of it and learns the rest from an online video. She's a member of our subdistrict dance team and has a perfect figure even though she's 56 . She's very busy with

\footnotetext{
${ }^{2} \mathrm{~A}-\mathrm{do}$, also known as Chengyi Du, is a famous Singaporean singer.

${ }^{3}$ Jamyang Dolma is a young Tibetan singer who was famous for To Wander, The Lover Story of Western Sea, and such typical songs about Tibetan culture and landscape.

${ }^{4}$ The Angel Has Arrived in the World is a classic song of Yue Opera A Dream of Red Mansions, which is adapted from a famous Chinese classical novel of the same name, also known as The Story of the Stone. The duet song is by Daiyu Lin and Baoyu Jia, the heroine and hero of the novel, explaining their subtle first impression and excitement about each other.

${ }^{5}$ The song came from the famous film, modern Shanghai Opera Last Night Love made in 1986, which talks about the regret and hope of a remorseful husband who became a criminal.
} 
performances, competitions, and looking after a paralyzed parent. It's very hard for her to arrange a time to teach these children.

$\mathrm{Q}$ : The last performance of the side drum band had some quite different kinds of dance.

Sun's mother: There was a fan dance, Xinjiang dance, actually they learned all kinds of dances. They keep practicing new dances; they probably have a dozen dances all together.

They enjoy dancing so much; the parents even make some costumes for their New Year's show and parties. For New Year's show, all of the subdistrict teams in Hongkou District perform their own shows together. They've already started to prepare this year's performance for the show. My daughter is a part of the side drum and flat drum shows; some of them will sing, but she's not good at singing.

Q: Does Yijie have a partner in the side drum band?

Sun: Yes, I have two partners, Xiao L and Xiao D.

Sun's mother: Dancing is Xiao L's main interest; he practices square dance in the park every evening. He enjoys dancing so much; he has a very good facial expression for dance.

There is a square dance team nearby our other home, an apartment in the Anting District, near Yijie's dad's workplace. Every evening, some grandpas and grandmas dance some pretty complex and delicate dances in the community square. I like these dances a lot, but she doesn't want to join them even when I ask her to dance at the back of the team.

Q: Young girls are always a little bit shy.

Sun's mother: My daughter likes to play with her phone, but Xiao L doesn't like to do that; he dances every evening.

Sun: He only likes dancing.

Sun's mother: Our subdistrict team's dance, Dancing China, won the silver medal at the Shanghai Disabled Persons' Talent Show recently, it's a singing and dancing show for disabled people.

Sun: Dancing China and Little Apple.

Sun's mother: I was there as their make-up artist (shows a picture of the performance).

Sun: We found our costumes on the Internet.

Q: They're pretty clothes.

Sun's mother: They danced pretty well, but lost in the second round.

These are her most recent artistic photos. They're expensive but I like to spend money on these for her. She took some artistic photos when she was 20; now she's 30 and I decided to let her to take another set (shows her daughter's artistic photos while talking).

She's been to quite a lot of cultural events in Shanghai and TV shows as well. I'm always there with her, so I've been to many different places.

Sometimes we don't know a child's true potential, but she really likes recreational and sports activities and enjoys dancing and singing. There are 40 to 50 children in our team, she is one of the active ones, but before this I had no idea she could dance and sing. 
Q: What did you do at the television station?

Sun's mother: It was an event for Special Olympics in 2007.

Sun: Zhiying Lin $^{6}$ came and took a picture with us; he also gave me a signed CD. We had a drawing class on Wednesday afternoon as well.

Sun's mother: This teacher is well known and has a lot of students, she's one of our volunteers, too. She used to come with her husband before he went abroad, and they even paid for the painting materials for the children.

As part of the "Improving Shanghai People's Physical Fitness Project," the children practice one of the "All Games of Shanghai" sports—wiser ball—a kind of ground-based ball game, every Thursday.

Sun: We have to hit the numbers.

Sun's mother: It's like snooker but on the ground. The sport is still new to us and the students felt awkward at the beginning, but we all grew to like it later, because this game is also good intellectual practice for them. (She asks Yijie) how about Friday's plan?

Sun: Sometimes some people come to us for activities.

Sun's mother: These children are getting smarter and more engaged with the world as they grow up. Generally speaking, they're much better than they were. Teacher Zhou thinks about the children's condition a lot. She suggested if they can communicate and become interested in different things, this will give them an opportunity to cooperate with different volunteers and volunteer companies. They come every other Friday, not every Friday. The volunteers from Bright Dairy and the Communist Youth League of Shanghai taught them to sing and took them to a farm. All of them have creative and different ideas, but recently, most of the volunteers come from the Leshanhui Foundation and Mary Kay, a big company. Mary Kay's volunteers come monthly and arrange all kinds of different events for the students.

Q: What's the Leshanhui Foundation?

Sun's mother: It's a social organization, a public welfare foundation.

Sun: All of them wear yellow vests.

Sun's mother: One activity they do is teaching students to draw on straw hats.

Sun: Face painting.

Sun's mother: They draw all kinds of things. Another time, the volunteers brought material and taught them to do paintings with green, yellow, and red beans. It's why the children are always so excited to see the Leshanhui Foundation's volunteers, because they come with different and interesting things every time. The students like to take pictures after they've finished their handicrafts. Here are some pictures of their handicrafts (takes out some photos), this is a mushroom made with colored beans and some cakes, but my daughter doesn't like baking. If she's made some in the district DPF center's class, she takes them to the Sunshine Home and shares them with her classmates.

There are so many good-hearted people who are concerned about these children. For the DIY classes, the children need money to buy equipment and materials. So, we contacted a life care crowdfunding organization, a very good organization, which

${ }^{6}$ Zhiying Lin, also known as Jimmy Lin, is a Taiwanese singer, actor and racing car driver. 
helped us sell the children's handicrafts online. It's why we had money to buy an oven, baking equipment, and material for baking biscuits and bread.

We have another baking class on the 30th, where some volunteers will teach them to bake individually. It's very good for the children. At least it's a thing they can do by themselves even though they can't learn complex skills.

Q: Do you make cakes after you learned to bake?

Sun's mother: No, she only plays the online baking game. They also have a Women's Salon here; sometimes they make nougat together and invite me to join them. Well, I enjoy it very much. It's their hand made nougat (takes out a bag of nougat).

Sun: Only the female students make nougat, the boys don't do it.

Sun's mother: Another time, supported by an NGO foundation, they made handmade soap. The teachers contacted the foundation and raised the money for the girls to arrange activities in the Women's Salon.

It's so hard to teach them new things but these volunteers insist on coming here to help them. We appreciate this volunteer work and their precious time. It's not easy for them to find the time to come when they have a busy work schedule. We also had some undergraduate volunteers who came from East China Normal University and Shanghai Jiaotong University, but we lost touch with them when they graduated, such a shame. These young people are so smart and would leave us, the older generation, way behind.

Q: Did Yijie make any new friends from the volunteers?

Sun's mother: (asks Yijie) Did you? Her involvement with the volunteers was just taking pictures or playing together, but she isn't in touch with them on We Chat yet. (talks to Yijie) It's not something you're very good at, you don't like to keep in touch with them, but some other students like to exchange WeChat addresses with those volunteers.

Sometimes she brings back handmade wonton or moon cake that she's made with the help of the Sunshine Home teachers. It's pretty good.

Once my daughter said she learned how to make a fried egg and tomato dish with the teachers. It surprised me, so I went to the teacher to check this, because I'd never seen her cook before. One day, the Sunshine Home arranged a cooking competition for the students, they had to tell us what food they needed for their dishes for that day and they cooked in groups in the big hall. The parents were the judges.

As a person of 60 , I enjoy spending time with these children even though they always speak without thinking about other people's feelings, but they're so pure.

The Sunshine Home's teachers are loving, but at the same time, practicing a quite strict discipline. They're different to other people who might think "What's the point of teaching them? It's just useless, nobody will learn anything."

There's a female teacher, a short woman with clever hands, she can make all kinds of different things, she is very patient with the children.

Sun: She's good at knitting, origami, and sign language.

Sun's mother: The district DPF office arranges a summer camp every year, most of the independent students — who can wash and dress themselves-from the Sunshine 
Homes in the area have the chance to go. Usually there are two teachers who go to the camp in the Songjiang District for 4 days.

Sun: We have classes there.

Q: What kind of classes?

Sun: About personal skills, to be a "little journalist" or a volunteer...

Sun's mother: They arrange some activities for the students; they let some of them act out a volunteer role and others play the editor of a newspaper.

Sun: Yes, we have to write articles, the "little journalists" have to write something.

Q: How many students altogether?

Sun: Two.

Sun's mother: Every subdistrict can send two children to this district event.

Sun: We sang karaoke and watched movies there. One time, several students and I went out of the camp for a sports event.

Sun's mother: She was so happy during the Summer Camp, even happier than she is at the Sunshine Home.

Sun: We have a medal presentation, too.

Q: I saw Yijie's varnished nails for the first time when I met her, did she do them by herself?

Sun's mother: No, that was her auntie who did that for her before our holiday. Her auntie tried very hard to take her to the nail salon and get her nails done.

Q: Yijie is the recreation and sports secretary in the class, isn't she? What are her duties?

Sun: I teach them something about literature and art or read the newspaper.

Sun's mother: For example, if they start learning a new dance, she'll be one of the first to learn it and then she will teach the other students.

Sun: We also have to attend regular activities of the Communist Youth League to discuss about striving for the great cause of communism.

Q: When did you join the Communist Youth League?

Sun's mother: (finds Yijie's CYL certificate) In 2009.

Q: Is Yijie's native place Zhejiang Province?

Sun: Ningbo in Zhejiang Province.

Q: Yijie's really talented at sports, dance, and handicraft?

Sun's mother: That's right. This time Teacher Zhou said we are definitely going to make a special gift for everybody in your team. She (points to Yijie) and little Y's mother is in charge of gift making.

Sun: I start making the gifts when I come back home until9 p.m. I start working immediately after my dinner.

Q: Yijie is very popular among the Sunshine Home classmates?

Sun's mother: That's right. My Yijie is good at the "monkey king" performance, too. If you spend more time with these children, you'll realize they are very genuine and cute and don't have any bad thoughts. We really appreciate the government's Sunshine Home project, it's such a great thing for these children; at least it provides a place for them, otherwise I can't think what we would do with them.

Sun's mother: Some children from the other Sunshine Homes envy Yijie as well, because our Sunshine Home has more activities and the children are happier. Children 
like them can be reluctant to study; it would be impossible to let them take serious classes at the Sunshine Home. It wouldn't work because they get bored with the normal way of studying and they only like to engage in recreational activities. These children like to do things which make them feel fulfilled.

People always say that God never shuts one door without opening another. Our Yijie has a talent for recreational and sports activities; all of these children have their own strengths in different fields. But it's hard to say if she will engage with society, I think she will never be a part of the society. You can't tell that she has a problem by looking at her face or appearance until you've talked to her for a while. Then you find out she is very difficult to communicate with and long conversations are just too much for her. Right now, she's part of this big family of the district DPF center. (She looks at Yijie) Can you tell us what you like apart from the computer and mobile phone?

Sun: I like handicrafts, making beads, that kind of thing...

Sun's mother: I don't have any of the things she made from beads with me, but I'll show you later.

Sun: I made them myself.

Sun's mother: She learned to make beads at the Sunshine Home and then started to do this herself.

Sun: I like to sing and draw as well.

Q: What's your favorite game?

Sun: Some QQ games, "Pair-up" for example, or mahjong, Puzzle Bobble.

Q: You play quite a lot of games. Do you watch movies?

Sun: Of course, I watch movies on my phone.

Q: What kind of films do you like?

Sun: Some TV programs like Journey to the West, Romance in the Rain, and My Fair Princess.

Sun's mother: She's obsessed with these programs.

Sun: I'm following Magical Dog Seven at the moment.

Q: What does Yijie do at the weekend apart from her everyday activities?

Sun's mother: She comes here to the district DPF center at the weekend.

Sun: I come here for the activities.

Sun's mother: She goes to the Sunshine Home from Monday to Friday and comes to the district DPF center for the weekend activities. She has a very busy timetable and I've to go everywhere she needs to go.

I'm 60 this year. I took early retirement when I was 45; after that, I didn't take any other jobs, but decided to look after her.

Q: Do you think there's something the Sunshine Home could do better?

Sun's mother: I think it's pretty good, this Sunshine Home runs more activities than the others. Sometimes, for me, I feel their busy schedule is too much. I don't think they get enough practical work; they can be quite lazy children. I wish we could arrange more practical activities for them. It doesn't matter what; housework practice or washing clothes, all of these practical activities would be good for the children. 


\section{Involvement in Sports, Being Healthy and Cheerful}

Q: When did Yijie participate in Special Olympics for the first time?

Sun's mother: In 2007. Special Olympics and related sports are special events for the intellectually disabled and all district and subdistrict DPF offices arranged their own Special Olympics Game events at that time. Firstly, these children can enter some games at district level as an individual athlete; then secondly, the municipal sports committee will select athletes from these events. My daughter won several medals at our district sports and games, (she takes out some medals) these are her medals for first, second, and third places, this one is our subdistrict's group medal.

Sun: I won first place for the bicycle race as well, the Tandem Race.

Sun's mother: This is the latest sports medal she won, just last Friday.

Sun: It's the Unified Run event.

Sun's mother: It's a biennial competition, Yijie always takes part. One team has 12 people, half the children and half the volunteers. I was a regular participant in the games, I joined four games with my daughter. Actually, she's always popular with her teammates, because she is light and much easier for other people to carry around. One time we won a gold medal for the Unified Run, here... (She shows the interviewer the medal). I couldn't take part in this year's competition because of my back problem. This time they won second place in the team event, it's a very hard game for everybody.

Sun: These are my gold medals.

Sun's mother: They are also a record of her growing up day by day. I remembered these medals last night and decided to bring them with me today. There are so many of them, 12 altogether. Yijie likes sports and wanted to join all kinds of sports events, so I just let her enter these games.

Q: It's brilliant.

Sun's mother: This is a medal for sixth position in a table tennis competition in Shanghai, and here are some medals from basketball shooting hoops, 100-meter sprint and other competitions.

Sun: I won the Rhythmic Gymnastics Competition as well.

Sun's mother: The sports games for these children are not really about winning medals, but when we became involved we started to think that we should do our best and try to win. We treated the games seriously, following a very busy training timetable and putting a lot of effort into them.

Q: What else can you tell me about Yijie's training?

Sun's mother: The cycling race includes Singles and Doubles Races. They use a tandem bike in the doubles race like the one you can see in the park, one bicycle with two seats and two sets pedals for two people. In the beginning Yijie was a Single Race cyclist, but she was too weak for this sport, so she had to change to the double race and started training with a stronger girl. We paid a lot of attention to practice and borrowed the sports ground from Miyun Road School for them. They trained with the school coach once a week, which was a very formal schedule for them: the coach put a lot of effort into their training and he was quite strict about it. 
My daughter isn't a strong person, she tried her best to get through the training. I was there with her on the day of the competition and I was genuinely impressed with her performance, she finally won a gold medal.

Although Yijie is a small person, she's better than lots of people without disability at (basketball) shooting hoops, it's quite interesting. (She asks Yijie) What was your final position in shooting hoops?

Sun: I don't remember now.

Sun's mother: She forgets the results of the competition, too! A bad memory is one of her biggest disadvantages, I have to remember things for her. I keep telling her: "You have to remember things yourself, because my memory gets worse as I get older." I remember when she came back from the competition and told me the result, I was totally amazed. I never expected her to win anything at this game.

Q: How long do they train before a competition?

Sun's mother: They're having regular exercises guided by the teacher all the time, they only do special training for a competition when they have been told by the district DPF office to prepare for an event.

Q: I watched Yijie's table tennis competition last time, she was fantastic, she's good at "smashing." (see Fig. 1).

Sun: I won sixth place in the table tennis competition.

Sun's mother: Yijie has been involved in lots of events; she likes to go to all the games.

Q: That's pretty good.

Sun's mother: Exercise is always better than sitting down and doing nothing.

$\mathrm{Q}$ : Yijie, is there anything that impressed you most about these events?

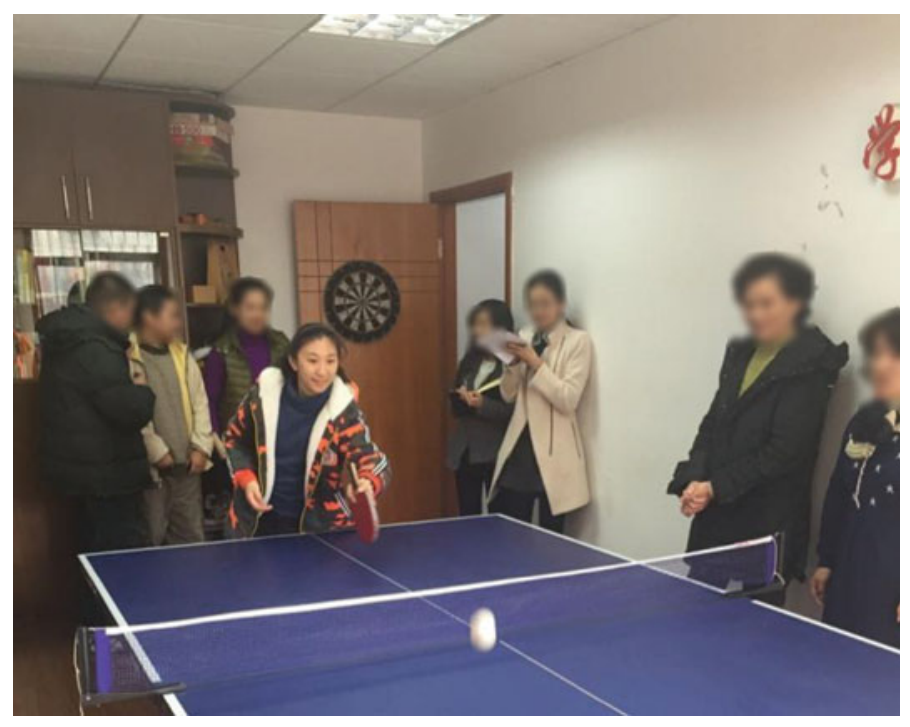

Fig. 1 Yijie Sun taking part in a table tennis competition 
Sun: I don't think so, I just enjoy the games. But I'm even happier if I win a medal.

Sun's mother: Yijie only enjoys competitions that she likes, but she doesn't understand very much about other things yet. For example, once Yaping Deng ${ }^{7}$ visited them, lots of children wanted to take her photo, but Yijie wasn't interested at all. Another time, Zhiying Lin came along and took a picture with her, but she didn't look like she was thrilled by this at all. The events make her happy, medals make her even happier. (She asks Yijie) Are you hoping to achieve anything else? Think about it.

Sun: The best thing is getting a good place or winning a medal (raises her thumb). I like to buy my mates a meal if I win. It's very me.

Sun's mother: As she grew up, she began to understand numbers and money better. Before she had any real sense of money, she would always buy her classmates meals when she received her monthly allowance, and everybody said what a very generous person she was. For her, 600 yuan is quite a lot of money, but she couldn't understand that it was for a whole season, it was supposed to be a 3-month allowance.

There are some other children in the team who have no sense of money; it's impossible for them to save anything. The only thing they understand is that the money belongs to them. Sometimes these children can also get a special subsidy for a competition or performance. Yijie doesn't like to keep the money herself and always gives it to me, but some of her classmates insist on keeping the money themselves.

I've told my daughter, as an adult, you might have to pay some unexpected bills, so you'd better carry some cash with you. After that conversation, she started keeping 100 yuan in her pocket all the time, but she hardly uses it. Lacking the ability to handle money makes me worry about her a lot; sometimes I can't even sleep when I think about her future. So, I have to let it go.

Sun: Once we practiced the Dragon Dance at the sports ground in the hottest of summers. It was a very hard job playing the tail, my face became red, and then I went a very dark color, but I didn't give up.

Sun's mother: It was very difficult practice, indeed.

Sun: It was a really tough job. We were at a military barracks.

Q: Why did you need to go to a military barracks?

Sun's mother: They went there to practice, because their coach was from the Armed Police troop, they have a Dragon Dance team there. We had two teams, a Dragon Dance team for the girls and a Lion Dance team for the boys.

Sun: It was a very hot summer, sweat was rolling down my face all the time.

Classmate's mother: We went to the military barracks once a week in 40 degree temperatures.

Q: The teacher told me that Yijie could handle the temperature and insisted on practicing during the hottest weather. I heard that she had to do two events at the same time?

Sun's mother: Yes, that time, after the dancing event, she ran to the Sports School for Children for a welcome ceremony for returning disabled athletes.

\footnotetext{
${ }^{7}$ A famous Chinese female table tennis player and Olympic champion, regarded as one of the greatest players in the history of the sport.
} 
Q: Did Yijie change in any way after her involvement with Special Olympics and other sports events?

Sun's mother: Actually, she changed quite a lot. The teachers at the Sunshine Home realized she'd changed as well.

Q: I was told by the teachers that Yijie had changed beyond recognition after the sports competitions.

Sun's mother: You're right. She was an introverted child, she hardly engaged in conversation when people talked to her, she was would be totally focused on her phone or computer and ignored other people. Some teachers said she was a little bit autistic. Now she's the opposite, she can engage in conversation and likes to discuss things she knows with people. Now she's an active, cheerful, and open girl.

Yijie used to be only close to me, she liked to share all her stories with me, but now she likes to share things with her friends. For example, if she won a medal in a competition, she'll take it to show her teachers at the Sunshine Home. If they're not there, she will take some pictures and share them with the teachers through WeChat. She keeps in touch with her teachers all the time, and some of them "liked" her pictures on WeChat and praised her, "You achieved this win through hard work." The other children like my daughter, they really respond to praise, and will always try harder to do better if you praise them.

Frequent exercise makes her fitter and stronger, and common diseases don't affect her as badly as before. Lack of exercise is the most common problem for intellectually disabled children, there are so many who are overweight because they just sit around after meals. Some children are different, they work very hard to deal with weight problems, they only become chubby if they don't get enough exercise. My daughter is totally the opposite of those children, she does exercises regularly and is full of energy. When we go on trips with other families, she is always the last to get tired.

So, the biggest changes to my daughter were that she became fitter, happier, and smarter.

Q: Yijie, do you feel any different after you joined Special Olympics and related events?

Sun: Yes, of course. I've changed a lot. I'm so happy and pleased to take part in group events with other people.

Q: Do you like to spend time with your teammates and friends?

Sun: Yes, I like to be with them.

Q: Did Yijie's social circle grow after she became involved in these sports events?

Sun's mother: No, I can't say that. To be honest, it's one of our great regrets, even though she participated in more events the new people she met were volunteers. It's impossible for her to find new friends by herself, very difficult. If she likes to go somewhere or do something outside the home, she still has to depend on her parents.

Q: Have you and your husband changed at all since Yijie became involved with sports?

Sun's mother: I'm so pleased about the way she has changed. I like to be a part of these children's events and I feel I'm still young when we're together, even though I'm quite old. Her teacher, Zhou, is the same age, and she does the same things as me, spends all her time and attention with her child and the other children. Yijie's father 
is happier that she has grown up as well. Especially that Yijie has become closer to him and communicates with him better. Sometimes she'll tell him about her day and what happened to her in the competition or send him some pictures through WeChat.

Q: Is there anything you'd like to say about the Special Olympic Games?

Sun's mother: I hope more people get to know these events and get involved, because my daughter and her teammates who benefited from the events is just a very small group. Most people don't know very much about Special Olympics yet.

\section{The Whole Family Looks After Her}

Q: What did you do before you retired?

Sun's mother: My husband and I both worked at Shanghai Automotive. It's a good factory but some tough personnel management policy decisions meant that the women workers had to retire at 45 while the male workers could work 10 years longer. I didn't take a part-time job after I retired, but my husband worked until he was 60 .

My husband said to me: "Our child is different and needs more attention, so please stay at home and look after her." He had to work harder for the family income. When he was younger, he didn't take a holiday for almost 2 years. His workmates thought this was quite strange and asked him why he had to work all the time. He told them that his wife had retired early and the family needed more money because of his daughter's condition. When their boss heard this and decided to give him some reasonable overtime. Usually the employees work 5 days and rest for 2 days every week, but my husband worked 6 days with 1 day of rest each week. He did this for years until last year when he just couldn't carry on with such a busy schedule.

I must say, our daughter is a very lucky girl, because her dad loves her as much as me. Her dad usually says: "I don't have any choice, because I have to look after our daughter. Her whole life depends on us." Today, even though he is retired, he still has a part-time job.

In our group, there are several pairs of parents our age and they're doing the same thing as us: the mother has retired and stays at home looking after their child, but the father is still doing a part-time job to make money for the child's future.

Q: Is Yijie able to live independently?

Sun's mother: Not at the moment, she can't look after herself. I taught her everyday skills when she was little, but the problem with Yijie is, when she's learned how to do something, if she doesn't get it right, it's very hard to get her to change. It's the same when she plays the side drum or a dance, correcting a wrong movement is a very hard job. We don't have any choice, we have to give her as much support as she needs. For people without disability, it's very difficult to understand these children's learning difficulties.

Q: Does Yijie help with the housework at home?

Sun's mother: She started learning housework very late because I looked after her too well. These days, she can wash her own clothes by hand after she's showered. Before dinner, she likes to help me set the table, that's all; she won't wash the dirty plates afterwards. 
I know it's my fault, I never gave her a chance to do anything in the past, even though I know that one day she'll have to face life on her own. She's grown up into a lazy girl already, the only thing I can do is help her learn housework little by little. Some children in our group are really good at housework, one boy who can't read keeps his home tidy and clean all the time. He's also good at bartering when he goes shopping, even better than some adults. These children are very interesting, and everyone has his or her own different characters.

Except for the 4-day summer camp every year, Yijie and I are never apart. People always see us together, sometimes if they see only me at the Sunshine Home, they'll be surprised and ask: "Why are you here by yourself? Where's your little tail?",

My daughter is always with me, I never let her go out on her own. I'll be pretty worried if she goes out by herself. I know I shouldn't be so overprotective towards her, but I just can't stop myself. It's easy in theory, but too difficult in practice. She knows how to take the bus to the Anting District, metro No. 4 first then change to No. 11, but I couldn't let her do this journey by herself. But some other children are very different; for example' we have a great child at the Sunshine Home who lives in the Songjiang District, he has to take a long bus journey to get here every day, nobody accompanies him.

Q: Have you ever thought about letting Yijie get a bus on her own?

Sun's mother: Yes, I've thought about it, but I don't dare to let her try. On the one hand, I'm retired and I have plenty time; on the other, her dad insists that I keep her company all the time. He always says, "Your primary responsibility is to take care of the child." If anything bad happened to her when I wasn't there, my husband would be so upset.

Sun: Once I was hit by a car.

Sun's mother: The same thing happened twice. Once I left her before they'd finished their exercises and one of the teachers said she'd send her back home afterwards. I got a phone call when I arrived home, she asked me to meet her down on the street because her bicycle had been hit by a truck. She was very scared after this accident. Another time, the same thing happened when she was riding her bicycle. She injured her foot that time. So, I always worry about her if she rides her bicycle without me being with her. Shanghai is too busy and there are too many bad drivers and cyclists everywhere. So, I have to keep her company.

Sun: My grandpa taught me to cycle; he encouraged me to learn.

Sun's mother: She learned to peddle the bicycle when she was very young, still at school. After that, she started to go everywhere with her bicycle. Many of our teachers and volunteers have bicycles as well; getting a bus here isn't very convenient for some people. If the teachers have to go shopping or somewhere, my daughter is always the only student assistant to go with them, because none of her classmates can ride a bicycle. She was pretty good at cycling before these two accidents happened. These bad experiences still haunt her; now she's timid and always peddles away when she sees a truck coming towards her. A child like her needs to pay more attention to understand the traffic laws and take them seriously, because they don't realize how bad an accident can be.

Sun (she's shy): I go through a red light sometimes. 
Sun's mother: I have to keep an eye on her all the time. Anyway, I'll do anything for her, I don't care what she wants to do, I just follow her where she wants to go, so I can help. Basically, I'm not a very open and sociable person, but I had to change for Yijie. I became part of their team, the assistant for their costume and make-up. That's my new job (laughs).

Q: Do you go to every competition with Yijie?

Sun's mother: Almost every time. When they're preparing for a competition, the parents and assistants get very involved, too. The children can only focus on their practice and performance; the parents have to do everything else for them. We know that overprotecting them isn't good; for example, we know they should sort out their own food and other things when they go to a competition, but we just can't stop ourselves from helping. If you've been to one of their competitions, you'd see the volunteers and parents running around the stadium getting things ready, but the children just sit there and wait for the presenter to call their team's name.

I've been to the Unified Run, a biennial competition four times in the past, but this time I couldn't go for health reasons. I told the teacher in charge that I couldn't go with them, and said to my daughter: "Mom is too old to run around the world with you anymore." This time, we had three tall, strong and nice male volunteers, they took the day off to help with the competition and took on the heavy responsibilities for the team-running through the rain to do stuff. I suggested to the teacher in charge that we should recruit more young volunteers, because we're getting old. These young people are very different, they're smart, active and have good social skills as well. Also, as young people, they have a much stronger ability to accept new things. Compared to us, traditional and outdated old people, they're good at using the Internet as a new way of teaching.

Several years ago, when we were younger, some teachers and I became the first students to learn new things from the young volunteers who couldn't come very often, and we would teach our children afterwards. Now, I'm old and phasing out my teaching duties slowly. There's another teacher who's in her seventies; for the children's happiness she still comes to the class with her daughter every weekend.

Q: Parents sacrifice so much for their children!

Sun's mother: Definitely; but she's not the oldest in our group, the average age of all the parents is older than that, only a few are younger than this mother.

To be honest, compared to many families in our group, my husband and I are in a better financial situation than those parents; it's not possible for many to pay for their kid's birthday party or for a trip.

I think about things in a different way, with the child's condition, the parents are the only people who will take her out, we can't shake off this responsibility. We have some nephews in our family, but they are very different to my daughter. They are ordinary children for their age, they can book hotels online or arrange other things, but my daughter can't do that. She has to rely on us, so we have to try our best to take her out on trips, as many as we can.

Nowadays, my daughter has become much choosier than before and she has higher requirements as well. For example, if we talk about destinations for our next journey, she'll choose an overseas trip rather than visiting places in China. 
Actually, we talked about this thing today, I told her it's not good if all she thinks about is going out or eating out, but it doesn't make any sense to her when I say she has to value the money her parents are earning. The teachers at the Sunshine Home always say we spoil the girl too much.

Sun: I haven't been to Beijing yet.

Sun's mother: Sure, her next trip will be to Beijing.

Sun: I've been to South Korea, Singapore, Malaysia, Thailand, Japan and Zhangjiajie.

Q: Did you all go to these places together?

Sun's mother: No, only Yijie and me. Her dad has to work and can't go on holiday with us. We'd like him to join us and asked him to save his holidays to go somewhere with us next time.

One time, when her dad was taking her on a trip, she was still having breakfast at home while the rest of the people in the group were waiting at the bus station. Her sense of time is bizarre; if you told her the tour sets off at 9 a.m., for her that would be the time to leave home. I tried to explain to her that she has to think about the time it takes to get to the bus station, but she couldn't understand me. Because of this, I've become the "Ms. Late" in the group. I always say to her: "Yijie, if I didn't push you along with the side drum band schedule, you wouldn't be successful." She doesn't have any independent initiative and needs somebody to keep her in line. Anyway, she depends on me too much.

Usually only Yijie and I go on the trips with the other parents, teachers, and their children. We go several times a year, because these children can't organize their own holiday trips. This year, we went to Singapore, Malaysia, Thailand, Sanqing Mountain, and Zhangjiajie. We didn't go on the last trip to Laozi Mountain because of my ill-health. Yijie can't go anywhere without me, so she missed the trip as well. When she saw the pictures that the other parents and children posted on WeChat after the trip, she was quite jealous. So, I told her that she shouldn't be upset because we can go with them next time.

We're members of a holiday agency who arrange the trips, so we have plenty of opportunities to go to places. I think while I'm still fit enough and before I get too old or sick to go with her, I should go on as many holidays as possible. One day I might have to stop, when I get too old or can't walk properly.

Q: Do you have a physical problem?

Sun's mother: I have a back problem because I did too much heavy labor when I was a young farm worker. It wasn't bad when I was younger, usually it took me a week to recover when my back went. The condition got worse as I got older, and it happens more often than in the past. It's very serious these days, sometimes I even can't walk or sit down. The doctor told me, the back is the central part of your body and you won't be able to move around properly with a bad back.

Classmate's mother: As parents, we don't have any choice, if we want the children to see the outside world, we're the only people who can do that for them. Nobody has the time to look after a disabled child. Even in our families, parents can't go on holiday with their children at the same time, usually the dad has to work and the mom is the only person who can go with them. In our family, it's the same situation 
as Yijie, I'm the only person who can look after our son and take him on holiday. We've been to Thailand, Bali, Singapore, and other places. Tomorrow, we'll fly to Yunnan; we'll fly three times in a week this time.

Once my son asked me: "Mom, please take me out while you're healthy, I won't do any more trips when you can't go with me." How could I not feel upset when I heard this?

As healthy as you guys are, you can go anywhere you want to go, but my son can't go anywhere without his parents. Seeing your 30-year-old son waiting for you to take him out is a really sad thing!

To be honest, it's hard to describe what it's like, as parents of an intellectually disabled child we have to swallow the bitterness of life alone, it can be a vulnerable and miserable life. I keep hoping that society will give these children special attention, but nobody helps us, we're on our own.

There are eight adults and their eight children in our small, close group. We usually arrange some activities to keep these children happy, like singing, dancing, or eating together. Our children are not able to, or can't make friends with ordinary people, but they can have lots of fun with their own kind. It's great for them to get a chance to sing, dance, and have fun and relax with other children.

People keep saying we should let our children be a part of society, but who would want to play with them? Yijie speaks better than the other children and she's able to put together some longer sentences, but others, like my son, can only speak a few words. Sometimes, I feel very upset for my son.

S's mother: I used to think I could just enjoy the moment as much as possible while I could play with my child and not think about the future. In our group, different families have their own difficulties. For example, in Xiao Y's family, their problem is scorn and criticism from the whole paternal family; this is very annoying. My extended family has a very different attitude towards my daughter, they insist on the same thing - compared to the other healthy children in the family, this special child needs more love.

As Shanghai natives, we inherited a very big house from our ancestors, so our extended family can share the space together. We have three generations under one roof, my parents still living with their siblings; when I was young, I lived with many cousins. I have three siblings, and my uncle, my father's older brother, has six children; in addition, my aunt, my dad's big sister, has three children-all of these children grew up together. We only moved out of the house when we were grown up and had our own families. We still live in the same community and see each other every week. My dad didn't want my siblings and I to move too far away from his place, two or three bus stops at the most.

In our extended family, there are two boys the same age as my daughter and all of them come from a single-child family. The oldest boy is half a year younger than my daughter, another one is one and a half years younger than her. The three children used to do everything together when they were little. They went to the same nursery and school, saw each other every day and were only apart after school. They would play together at the weekend when we went back to a parent's house. They were very close and got on with each other very well. One time, when the government 
demolished and relocated our old place, we had to move house, we even moved back to the family house for a while.

In this family, everybody loves and cares for my daughter very much. She is the center of the family, including my own parents, cousins, and their children; all of them are willing to do anything for her if she asks. Nobody looks down on my daughter at all, and all of them love her so much. For the adults and her cousins, she is the child of the family, even though she is the oldest of this third generation. Everyone understands that my daughter didn't choose her life, but unfortunately it happened to her, so why don't we try our best to look after her?

Since they graduated from the university, her two cousins have experienced a high pressure of life and work, my daughter will never have to feel this. I understand all about these young people and their stressful life and usually I say to Yijie: "You don't know how lucky you are."

Q: In some ways, her life offers a different kind of happiness.

Sun's mother: I agree with you, she's very lucky. She wouldn't get all our love if we'd had another child. There are some families in the same situation as us, they chose to have a second child, and this created a much more complex situation for the disabled one.

The children are sensitive to any unequal treatment from their parents; they might ask their mom: "Why don't you care about me and only look after the other child?" This situation could lead to conflicts and problems between the children. You might think this problem could be resolved by always reminding the second child, "You have to look after your older sister or brother when you grow up, she/he is your duty," and hope they adopt this idea as their own. But anything could happen when they grow up, they might stop listening to their parents one day.

We only have Yijie and we know she won't be able to become an independent adult, so I look to her two cousins to look after my daughter after we've passed away. They're very lovely children and quite close to me. Sometimes I say to them: "One day, when I get very old, I might ask you to look after me and Yijie."

In our group, some children are in a better financial position than my daughter, because they have found a way to get more governmental support. I only heard this news recently and didn't consider or ask about these policies in the past. Some people told me that making a complaint to the appropriate department is the right thing to do, but I disagree. I just accept this reality as my fate and tell myself to be calm. I don't want to be worrying about something that hasn't happened to us yet.

Q: Do your husband and you ever disagree about Yijie's education?

Sun's mother: No, we're always on the same side. I'm very pleased with our situation, and he never disagrees with me if I criticize the girl for something. If he wasn't on my side, there would be huge family conflict. Apparently, both of us support the child, he spoils the girl worse than me.

Q: Yijie's a lucky girl to have you, very lucky.

Sun's mother: I have to say she's a lucky child. Some families in the same situation as us might have very different stories to tell. There's a girl, the same age as my daughter, who comes from a divorced family and she gets less attention from both parents. The girl lives on her own, earns a little bit money, but often wastes it. She 
just hangs out with other people; sometimes she even buys a coffee for Yijie and the other girls if she can't find other things to do. I really can't understand her parents, how dare they let this girl wander around outside like this? There's another child who comes from a broken family too, both parents abandoned him when they had new families and new babies.

More families are willing to have a second child, but they can't treat the two children equally. There's a family I know, who first had a disabled daughter and later a non-disabled son; after the son came along, they sent their daughter to live with the grandma and refused to look after her, even though they were quite wealthy people. Anyway, like I keep saying, if you decide to have a second child, you must treat the disabled one equally.

Q: What do you usually do during your family time?

Sun's mother: When we're together my daughter is always the busiest one, on the phone all the time, playing with WeChat and games.

Sun: I like to watch films, online films.

Sun's mother: Sometimes, her dad likes to watch TV programs, especially war programs, the War of Resistance against Japan and China's War of Liberation. I use WeChat from time to time, because the teachers and volunteers from the district DPF center have a WeChat group, but I haven't checked the group messages since I had my bad back.

If I'm free, I have to travel to the Anting District to look after her dad; my husband can't cook, and if I don't go there, he lives off takeaways or frozen dumplings. It's quite a journey between home and Dad's workplace, so I usually have to stay a couple days. At the same time, I can't stay with my husband for longer than 3 days because I have to come back for my daughter.

Q: Sounds very hard.

Sun: She always starts the housework straight away when she gets back home.

Sun's mother: I don't have any choice; I have to run between the two places. Some people talk about how their retirement is boring and I can't understand it at all, I'm so busy, I never have any time.

Compared with ordinary young people, these children are free from worry. When you graduate from university, you and your classmates have heavy competition for jobs and it's hard to be in control of your own time. You can't take a holiday or trip when you feel like it. My daughter keeps asking her two young brothers, "Why don't you go out?" I have to explain to her, they have to work, it's stressful, they can't go somewhere when they want, like you do.

Classmate's mother: As parents of these children, their happiness is ours as well, if they are happy, so are we. Parents are the only people who can look after these poorest children.

\section{Better Not to Think About the Future Too Much}

Q: Have you ever thought about Yijie getting married?

Sun's mother: Yes, of course, but in her group, every child has their own special condition and desire. For example, Xiao Y wants to get married and wants a wife, but my daughter, she's still like a child. She can't think about marriage or starting a 
family yet, so I just let it go. If she got married to a person without disability, that could be a problem for their relationship. So, if she wanted to get married, a disabled man is the only choice for her. Sometimes when I think about what will happen after my husband and I pass away; I think maybe if she gets married, it would be a good thing for her and they can look after each other without us.

For some children in the group, marriage is something they want, but it isn't an issue for my daughter at all.

There was once a very nice girl who stayed at the home, she looked normal and nobody would have known that she had a problem until she started talking. Later, she married a taxi driver who lived downstairs. On their wedding day, the guy promised the mother, "Please stop worrying, I promise I'll try my best to look after her," but 3 months later this young couple started quarrelling. Before they got divorced, this was before their first wedding anniversary, they even argued at the subdistrict office. After that, she remarried a man with the same condition as her; they're a good match and get on with each other very well.

I have to say, it's very rare for these children to get married. Anyway, marriage is hard work even for ordinary people. There's another young girl in our group, she fell head over heels in love with a man, she'd cry and refuse to eat if she couldn't see him. Hard to blame the girl alone for this family issue, I think her parents had to take responsibility for this difficult situation.

Anyway, I won't let our Yijie out of my sight; if I did, I wouldn't stop worrying. She and her classmates are very innocent and naive, and the outside world is too complex for them; there are many good-hearted people, but quite a few bad ones who can be very harmful. When she studied at the school, I would collect her twice a day and never missed once. Her teacher told me that I loved my girl too much.

I always tell Xiao Y's mother, your son is independent because he has Down syndrome, but not intellectually disabled, otherwise he might have been cheated by some people many times. Xiao Y is a more sophisticated boy, very different from the other children in the group. He doesn't just say the first thing that comes to mind, he usually thinks about your question before he answers.

These intellectual conditions are the reason that parents and families give more attention and love to their children, but it mustn't turn into something that makes them a careless or nasty person who only think about themselves. As families, we have to reason with our children, maintain the correct standards of behavior and give them the right kind of family education.

Q: What do you wish for Yijie?

Sun's mother: I hope she can be a little more sensible one day, because sometimes she's too childish. I get older every day, sometimes I feel ill or too tired to do anything, but if I don't keep telling Yijie over and over to help me with the house work, she won't do anything.

I felt recently that my daughter is too naive, especially with her lack of social skills. She lives in the community and that makes me worry about her relationship with (open) society more; she needs better social skills; they are very important for her. 
I don't want to discuss my expectations for her future, I would rather focus on her present life. To be honest, if people in our situation think about the future too much, they won't be able to sleep. The best thing is to forget about this, it doesn't mean anything to us: we just live for today and don't plan for the future.

In addition to the group of children like ours, there are other four groups of disabled people: those with a physical disability, deaf-mutes, those with mental problems, and blind people.

Sun: Association for the blind. (She corrects the title of the association that her mother just mentioned.)

Sun's mother: We usually say all disabled people are vulnerable, but I believe children with intellectual disabilities are the most vulnerable in the group. This intellectual condition that effects their brain, they need adults to think for them. In other subgroups, for example some deaf-mute people, they can be cleverer than ordinary people. They're very smart, and they know what they want and how to negotiate with other people. They know how to ask the district DPF office for something they need. Sometimes their demands make the district DPF leaders feels slightly awkward.

Intellectually disabled children (points at Yijie) don't know how to ask other people for help. They need their parents to help to explain their needs to the institute and the parents or guardians have to do everything for them. Compared to intellectually disabled people, mental patients are in a better situation as well, because they only lose their mental control while they're sick. The rest of the time they're almost the same as people without disability. As the most vulnerable subgroup of all vulnerable groups, I want my daughter and her kind to get more attention. That's all I ask for.

Q: I hope Yijie has a happy life forever. Thank you for the interview.

Sun's mother: You're welcome, it's been my pleasure.

\section{Interview with Yijie Sun's Teacher}

Interviewee: Yijie Sun's teacher

Interviewer and writer: Puyu Zhang

Interview date: December 7, 2016

Interview place: The Sunshine Home in Shanghai.

\section{She has changed a lot since she joined us}

Q: When did Yijie start coming to the Sunshine Home?

Teacher: She joined us around October 2005 when we opened.

Q: Do you remember the first time you saw her?

Teacher: I wasn't there at that time, because I hadn't joined the center. I knew their assistant, Teacher Feng (points at the teacher near the doorway), he told me Yijie was very quiet to start with, hiding behind her parents and didn't like to talk to anybody.

Q: I guess she's changed quite a lot since then? 
Teacher: She is the student who has undergone the biggest change at our place. When I came to the center, she spoke very little. I remember she cried very often, cried for all kinds of things and she was a slower learner in her studies and handicrafts. Now she can do all of these things, she talks more, and she's become a good dancer.

She learned all kinds of sports here. For example, she didn't know how to play table tennis or badminton; at the end of their first badminton exercise, she couldn't even pass the shuttlecock across the net. The only thing she could do was serve and if the shuttlecock went over the net, her job was done.

The only problem for her now is that she's still a little bit timid when she meets people; she is only able to talk in a group if she is well prepared, otherwise she won't speak.

Q: What has impressed you about Yijie since you met her?

Teacher: Her behavior during Special Olympics in 2007 was very impressive. With such a tight schedule for the dance shows, as a dancer performing in several dances, she had to run from one show to another. In the hot weather, she had to change clothes and run from one stage to another, but she never gave up and worked very hard. I've never forgotten this.

\section{A Popular Person but Has No Work Skills}

Q: What do you think about Yijie's general character? Is she an introvert or extrovert?

Teacher: I think she's an introverted person, but she can be an extrovert and open when she concentrates on her dance or exercise. It's hard to tell which is the real her. Sometimes it depends on your relationship with her, she likes to talk with people she knows. If she thinks you're friendly and kind, she'll have a lot to say.

Q: Does Yijie have many friends?

Teacher: She has a lot of friends and she's very popular, though basically, she's a quiet person who gets on with all of her classmates very well. At our center, both Xiao Q and she are the most popular people, but Yijie has a better temper than Xiao Q. Anyway, she's a very innocent child, just like a child.

Q: Does she arrive on time?

Teacher: (He shakes his head and laughs) she's often late, quite often, but there's nothing we can do about that because it's part of her mental condition. She can think properly when she's in the right mood, but she can lose the control when her mood isn't right. For example, she can't wake up on time even though she knows she should get up, but she can't open her eyes.

Q: Do you think Yijie will be able to work one day?

Teacher: I don't think so. She does things very slowly. She can do some DIY work, but with no restrictions, she can't do things on time. For example, during mealtime, even if you sit next to her to hurry her along, it doesn't work. Compared to Xiao Q, she can't do a proper job; otherwise we would probably have referred her somewhere already.

We've helped several students find a job; one works at a check-out at McDonald's and another makes screws, but we can't find the right job for Yijie. We tried sending her to the Sunshine Factory, but she wouldn't stop crying from the time she arrived, and we had to bring her back home to her mother. There's an interesting thing, but it's 
hard to explain, some moderately disabled people can do a proper job, but some with a much milder condition can't work. The latter group might be good at something different but not work, they can't be a part of society.

Q: Thank you for talking to me.

Teacher: You're welcome.

\section{Interview with Yijie Sun's Classmates}

Interviewees: Yijie Sun's classmates

Interviewer and writer: Puyu Zhang

Interview date: December 7, 2016

Interview place: The Sunshine Home in Shanghai

Q: How's your relationship with Yijie?

Classmate 1: Pretty good.

Classmate 2: Yes, we're good.

Q: What's she like?

C1: Pretty good.

C2: She can play Monkey King and she's good at handicrafts.

$\mathrm{C} 1$ : Her handicraft work is super good.

C2: Most of the handicrafts in the room were made by her and our Teacher L.

$\mathrm{C} 1$ (She points at one piece of handicraft): This one was made by her, too.

C2: Yes, made by her mom and her.

C1(Points at another piece of handicraft): She made this one as well.

$\mathrm{Q}$ (Points at a Chinese knot): How about this one?

C1: This one was made by her, too.

C2: All of these things were probably made by her, including the snake.

$\mathrm{Q}$ : Yijie is such versatile person and she's good at dancing too.

C2 (Asks classmate 1): She has a dancing partner, someone called D, right?

(A kind classmate introduced Yijie's dancing partner.)

Q: Are you Yijie's dancing partner?

D: Yes.

Q: What's your relationship like? Do you play together often?

D: Well... We don't have free time for playing. We are too busy with studying or practicing the side drum or the flat drum. Sometimes LZ teaches us new dances, the Xinjiang Dance for example.

C3: LZ dances very well.

D: Because his mom teaches dance, his mom is our teacher. She's our drum team teacher.

Q: Did Yijie and you ever perform a pas de deux together?

D: Yes, of course.

Q: What did you dance together? 
D: We danced The Girl of Daban Town ${ }^{8}$ and Lifting Your Veil ${ }^{9}$ and so on, quite a few.

Q: Do you make a good team?

D: Well... (He shakes his head) we danced in different groups. The dancers are divided into different groups, and we dance in several rows.

Q: I thought they were pas de deux?

D: Not really, only The Girl of Daban Town and Lifting Your Veil are pas de deux, but the rest are group dances.

Q: Okay, I see. Thank you.

D: Not at all.

\section{Observation of Yijie Sun in the Drum Team}

Observation date: 9:00-11:40, November 27, 2016

Observation place: Hongkou District Disabled Persons' Federation, Shanghai

Observer and writer: Puyu Zhang

\begin{tabular}{|c|c|c|}
\hline Time & Content & Observed activities \\
\hline 9:20 & $\begin{array}{l}\text { The observed arrives and starts the first } \\
\text { dance Chinese Kung } F u \text { as the principal } \\
\text { dancer, her body movements are fluid }\end{array}$ & $\begin{array}{l}\text { The start time is } 9: 00 \text {, but Yijie Sun is } \\
20 \text { min late }\end{array}$ \\
\hline $9: 23$ & $\begin{array}{l}\text { Yijie is watching the teacher very } \\
\text { carefully while the teacher corrects the } \\
\text { other students' movements }\end{array}$ & \\
\hline $9: 25$ & Break time & \\
\hline $9: 35$ & Dancing Bright Spring Day & \\
\hline $9: 45$ & Break time & $\begin{array}{l}\text { The teacher says, she met Yijie in } 2006 . \\
\text { In the beginning, Yijie didn't move very } \\
\text { much on the stage, but now she is } \\
\text { transformed into a person with a good } \\
\text { attitude, who likes singing and dancing } \\
\text { very much }\end{array}$ \\
\hline 10:00 & Dancing Fist of Gymnastics & $\begin{array}{l}\text { This is a kind of martial arts gymnastics } \\
\text { and students shout "Hey" and "Ha" } \\
\text { during practice. But Yijie's voice is very } \\
\text { low }\end{array}$ \\
\hline 10:05 & $\begin{array}{l}\text { Yijie says goodbye to her mother when } \\
\text { she's leavin }\end{array}$ & \\
\hline 10:12 & Break time & \\
\hline
\end{tabular}

${ }^{8}$ It is a popular Uyghur folk song translated into Mandarin.

${ }^{9}$ Another well-known Uyghur folk song translated into Mandarin. 
(continued)

\begin{tabular}{|c|c|c|}
\hline Time & Content & Observed activities \\
\hline 10:15 & Dancing Seeing Off the Red Army Troops & \\
\hline 10:22 & Dancing Little Apple & \\
\hline $10: 25$ & $\begin{array}{l}\text { Dancing a part of Horse Pole, Moonlight } \\
\text { over the Lotus Pond, and other dance }\end{array}$ & $\begin{array}{l}\text { Yijie isn't familiar with one of the dances, } \\
\text { and she has to follow the other dancers }\end{array}$ \\
\hline $10: 35$ & $\begin{array}{l}\text { After the side drum band practice, } \\
\text { students prepare fora baking class }\end{array}$ & \\
\hline 10:45 & Putting on face masks and gloves & \\
\hline 10:50 & $\begin{array}{l}\text { Yijie turns back to watch the volunteer } \\
\text { while he teaches students in the other } \\
\text { group }\end{array}$ & \\
\hline 10:51 & $\begin{array}{l}\text { The teacher shows Yijie how to roll up a } \\
\text { bag by hand and fill it with chocolate } \\
\text { sauce }\end{array}$ & \\
\hline 10:53 & Stirring the chocolate sauce. & \\
\hline 10:55 & $\begin{array}{l}\text { Yijie leaves the classroom and joins the } \\
\text { Branch League meeting }\end{array}$ & \\
\hline 11:03 & $\begin{array}{l}\text { People study the sixth Plenary Session of } \\
\text { the 18th CPC Central Committee spirit } \\
\text { together }\end{array}$ & \\
\hline 11:06 & & $\begin{array}{l}\text { Observed sits next to the teacher who } \\
\text { nods her head often when she's reading } \\
\text { the newspaper }\end{array}$ \\
\hline 11:09 & & $\begin{array}{l}\text { During the part of the personal statement } \\
\text { in the meeting. Yijie says "We should } \\
\text { love the party, love the country, care } \\
\text { about the party and care about the work of } \\
\text { the League Branch" }\end{array}$ \\
\hline 11:20 & The meeting finishe & \\
\hline $11: 35$ & $\begin{array}{l}\text { Students stand in a queue for the freshly } \\
\text { baked cakes }\end{array}$ & \\
\hline 11:40 & $\begin{array}{l}\text { The cakes are handed out and a picture is } \\
\text { taken together }\end{array}$ & \\
\hline
\end{tabular}

\section{Observation of Yijie Sun at the Sunshine Home}

Observation date: 9:00-15:00, December 7, 2016

Observation place: The Sunshine Home in Hongkou District, Shanghai

Observer and writer: Puyu Zhang 


\begin{tabular}{|c|c|c|}
\hline Time & Content & Observed activities \\
\hline 9:09 & Practicing the People's Radio Calisthenics & Yijie leads the practice \\
\hline $9: 13$ & $\begin{array}{l}\text { Yijie feels hot and takes off her coat after } \\
\text { the exercise }\end{array}$ & \\
\hline $9: 15$ & Practice the set-up Joint Health Exercises & \\
\hline 9:19 & Break time & \\
\hline $9: 21$ & $\begin{array}{l}\text { Practice the new dance The Red Star } \\
\text { Accompanies Me to Fight }\end{array}$ & $\begin{array}{l}\text { The dance teacher is a parent of a student } \\
\text { from the Sunshine Home }\end{array}$ \\
\hline $9: 23$ & $\begin{array}{l}\text { The teacher gives a special tutorial to } \\
\text { Yijie and three other students }\end{array}$ & $\begin{array}{l}\text { Yijie has a very good understanding and } \\
\text { "one word to the wise is sufficient" }\end{array}$ \\
\hline $9: 26$ & & $\begin{array}{l}\text { One of the movements is where Yijie and } \\
\text { another girl stand facing palm to palm, to } \\
\text { perform a circular dance. But there is } \\
\text { always something wrong with this part, so } \\
\text { the teacher has to stop and tell them how } \\
\text { to do it the right way }\end{array}$ \\
\hline $9: 30$ & & $\begin{array}{l}\text { Yijie gestures to a classmate who stands } \\
\text { in the wrong position. She moves forward } \\
\text { to the front of the stage a little bit }\end{array}$ \\
\hline $9: 32$ & & $\begin{array}{l}\text { Yijie is quiet and watches while the } \\
\text { teacher instructs the other students }\end{array}$ \\
\hline $9: 39$ & Repeating the movements & \\
\hline $9: 45$ & $\begin{array}{l}\text { All students stand up and learn the new } \\
\text { movement together }\end{array}$ & $\begin{array}{l}\text { The new movement is mocking the } \\
\text { monkey. Yijie demonstrates a cute } \\
\text { monkey posture }\end{array}$ \\
\hline $9: 49$ & & $\begin{array}{l}\text { Yijie learns the new movement very } \\
\text { quickly and she laughs at the other } \\
\text { students when they do something wrong }\end{array}$ \\
\hline $9: 51$ & & $\begin{array}{l}\text { When she realizes her mistake, Yijie } \\
\text { corrects her own foot movements by } \\
\text { carefully watching the teacher's action }\end{array}$ \\
\hline 10:00 & & $\begin{array}{l}\text { Her movements are very smooth after } \\
\text { practice }\end{array}$ \\
\hline 10:01 & Break time & \\
\hline 10:04 & Rehearsals for the whole dance & \\
\hline 10:16 & Break time & $\begin{array}{l}\text { Yijie is quietly chatting with classmates } \\
\text { while she puts her coat on and ties her } \\
\text { shoelaces }\end{array}$ \\
\hline 10:24 & Moving and arranging desks and chairs & \\
\hline 10:26 & $\begin{array}{l}\text { Yijie performs the monkey show for } \\
\text { everybod }\end{array}$ & $\begin{array}{l}\text { The Sunshine Home teacher says Yijie's } \\
\text { monkey performance is very vivid }\end{array}$ \\
\hline 10:28 & & $\begin{array}{l}\text { Yijie is a little bit stooped and the teacher } \\
\text { corrects her }\end{array}$ \\
\hline
\end{tabular}


(continued)

\begin{tabular}{|c|c|c|}
\hline Time & Content & Observed activities \\
\hline $10: 31$ & Plays table tennis & $\begin{array}{l}\text { Yijie is a very sophisticated performer } \\
\text { and she can smash the ball well at the } \\
\text { right time }\end{array}$ \\
\hline $10: 43$ & Lunch time. & \\
\hline $10: 47$ & $\begin{array}{l}\text { The teacher helps her take out the tendon } \\
\text { from the meat }\end{array}$ & $\begin{array}{l}\text { Yijie has teeth problems and can't eat any } \\
\text { hard foo }\end{array}$ \\
\hline 14:00 & Art class about "the secret of the colo" & $\begin{array}{l}\text { In the beginning, all of the students stand } \\
\text { up and clap their hands rhythmically and } \\
\text { say the slogan "I can do it if you can, I } \\
\text { could do it if you could" }\end{array}$ \\
\hline 14:01 & $\begin{array}{l}\text { The teacher tells students that he'll take } \\
\text { some stones for them for the hand } \\
\text { drawing session next tim }\end{array}$ & $\begin{array}{l}\text { Yijie sorts out her paper and pencils, and } \\
\text { actively interacts with the teacher. When } \\
\text { lots of students ask him for some stones, } \\
\text { the teacher jokes with them: "Who knows } \\
\text { how big and heavy my stone bag will be } \\
\text { next time?!" At this time, Yijie laughs } \\
\text { and makes another joke about the } \\
\text { teacher's words: "Pigsy is doing the } \\
\text { wife-carrying!" Her joke makes } \\
\text { everybody laugh }\end{array}$ \\
\hline 14:08 & $\begin{array}{l}\text { From time to time, she turns back and } \\
\text { looks at her good friend. She answers the } \\
\text { teacher's questions enthusiastically and } \\
\text { talks with her desk mate sometimes }\end{array}$ & \\
\hline 14:10 & $\begin{array}{l}\text { She's drawing with the teacher's guidance } \\
\text { and replies to the teacher's question } \\
\text { clearly }\end{array}$ & \\
\hline 14:11 & $\begin{array}{l}\text { The teacher talks about the first "secret": } \\
\text { the weight of color }\end{array}$ & $\begin{array}{l}\text { The teacher tells the students about light } \\
\text { colors, light compared to dark colors }\end{array}$ \\
\hline 14:12 & $\begin{array}{l}\text { The teacher asks the students to draw a } \\
\text { circle with the equipment they hav }\end{array}$ & Yijie asks: "Can I use the bottle top?" \\
\hline $14: 13$ & $\begin{array}{l}\text { The teacher asks students to draw two } \\
\text { circles positioned to the left and right }\end{array}$ & $\begin{array}{l}\text { But Yijie draws two circles positioned up } \\
\text { and down }\end{array}$ \\
\hline 14:14 & Choosing the right color & $\begin{array}{l}\text { Yijie borrows a color she doesn't have } \\
\text { from her classmate }\end{array}$ \\
\hline 14:15 & $\begin{array}{l}\text { Mixing the color: students put some color } \\
\text { pigments on the palette }\end{array}$ & \\
\hline 14:16 & $\begin{array}{l}\text { The teacher asks: "Which color is helpful } \\
\text { to improve the lightness?" }\end{array}$ & Yijie replays "white" loudly \\
\hline 14:17 & $\begin{array}{l}\text { The teacher asks Yijie "What are you } \\
\text { doing? Reducing the lightness?" She says } \\
\text { yes. And the teacher tells her: "You'd } \\
\text { better make a bright color afterwards" }\end{array}$ & $\begin{array}{l}\text { The teacher's instruction is to make a } \\
\text { lighter color but Yijie makes a less bright } \\
\text { color }\end{array}$ \\
\hline 14:18 & $\begin{array}{l}\text { Coloring the circle with a color they just } \\
\text { mixe }\end{array}$ & $\begin{array}{l}\text { Yijie colors very carefully, she paints the } \\
\text { outer circle first and fills the inside later }\end{array}$ \\
\hline
\end{tabular}


(continued)

\begin{tabular}{|c|c|c|}
\hline Time & Content & Observed activities \\
\hline $14: 20$ & & $\begin{array}{l}\text { While she cleans the brush. Yijie asks her } \\
\text { classmate: "How do you make a pink } \\
\text { color?" }\end{array}$ \\
\hline $14: 21$ & $\begin{array}{l}\text { Squeezes some pigment and mixes a pink } \\
\text { colo }\end{array}$ & She murmurs to herself: "It's not enough" \\
\hline $14: 23$ & & $\begin{array}{l}\text { She asks the teacher how to mix the right } \\
\text { color, the teacher points out her mistake } \\
\text { and tells her the right processes step by } \\
\text { step }\end{array}$ \\
\hline $14: 26$ & $\begin{array}{l}\text { The teacher tells the students to look at } \\
\text { the blackboard and Yijie raises her head } \\
\text { immediatel }\end{array}$ & $\begin{array}{l}\text { Yijie cuts into the conversation while the } \\
\text { teacher talks to her desk mate }\end{array}$ \\
\hline $14: 29$ & $\begin{array}{l}\text { She draws two colored circles up and } \\
\text { down, then starts drawing a set of scales }\end{array}$ & $\begin{array}{l}\text { Yijie gets two circles on the left and right } \\
\text { by turning her sketchbook } 90 \text { degrees to } \\
\text { the left }\end{array}$ \\
\hline $14: 32$ & $\begin{array}{l}\text { Yijie looks around at her classmates after } \\
\text { she finishes }\end{array}$ & \\
\hline $14: 33$ & & $\begin{array}{l}\text { She listens to the teacher keenly and nods } \\
\text { her head. She's looking through her } \\
\text { drawings }\end{array}$ \\
\hline $14: 35$ & & $\begin{array}{l}\text { She shows the drawing to her teacher } \\
\text { with a self-satisfied smile }\end{array}$ \\
\hline $14: 37$ & $\begin{array}{l}\text { The teacher reveals the second "secret" } \\
\text { that color has tast }\end{array}$ & $\begin{array}{l}\text { For example, red is associated with a } \\
\text { spicy taste, green is linked to a sour taste }\end{array}$ \\
\hline $14: 39$ & $\begin{array}{l}\text { The teacher lets the students choose six } \\
\text { different colors for sour, sweet, bitter, hot, } \\
\text { salty, and plain }\end{array}$ & \\
\hline $14: 42$ & $\begin{array}{l}\text { Yijie names the mixed color of brown and } \\
\text { green "bitter." The teacher asks her: } \\
\text { "What's the taste of your color?" Yijie } \\
\text { says: "Bitter, of course." The teacher tells } \\
\text { her to write the word at the front of the } \\
\text { color }\end{array}$ & $\begin{array}{l}\text { Yijie isn't good at writing, she copies the } \\
\text { words on the blackboard that were written } \\
\text { by the teacher, but even then, she gets the } \\
\text { words wrong }\end{array}$ \\
\hline $14: 44$ & $\begin{array}{l}\text { Yijie calls the color "sour" which was } \\
\text { mixed with yellow and green }\end{array}$ & $\begin{array}{l}\text { Yijie says the color she made is the color } \\
\text { of a lemon }\end{array}$ \\
\hline $14: 47$ & Yijie uses pink to represent "sweet" & $\begin{array}{l}\text { When one student asks: "What's the color } \\
\text { of sour?" Yijie replies immediately: } \\
\text { "Lemon is sour, isn't it?" }\end{array}$ \\
\hline 14:49 & Yijieuses red to represent "spic" & \\
\hline $14: 50$ & $\begin{array}{l}\text { Yijie asks one classmate: "What's the } \\
\text { color of salty?" The classmate says: "Soy } \\
\text { bean sauce's color, reddish-brown." Yijie } \\
\text { asks again: "How about plain?" The } \\
\text { classmate says: "white, you don't need to } \\
\text { mix it with another colo" }\end{array}$ & \\
\hline
\end{tabular}


(continued)

\begin{tabular}{c|l|l}
\hline Time & Content & Observed activities \\
\hline 14:55 & $\begin{array}{l}\text { Yijie shows her finished work to the } \\
\text { teacher }\end{array}$ & $\begin{array}{l}\text { The teacher comments on her work: "Well } \\
\text { done, but it lacks imagination, you need } \\
\text { to think about the question more openly" }\end{array}$ \\
\hline 15:00 & $\begin{array}{l}\text { The teacher sums up and announces that } \\
\text { the class is over. All the students stand up, } \\
\text { clap hands and repeat the slogan again }\end{array}$ & $\begin{array}{l}\text { Yijie enjoys the class very much and she } \\
\text { continues to discuss color and taste with } \\
\text { her classmates after the class }\end{array}$ \\
\hline
\end{tabular}

Translated by Huili Meng

Edited by Russell Murray

Open Access This chapter is licensed under the terms of the Creative Commons AttributionNonCommercial-NoDerivatives 4.0 International License (http://creativecommons.org/licenses/bync-nd/4.0/), which permits any noncommercial use, sharing, distribution and reproduction in any medium or format, as long as you give appropriate credit to the original author(s) and the source, provide a link to the Creative Commons license and indicate if you modified the licensed material. You do not have permission under this license to share adapted material derived from this chapter or parts of it.

The images or other third party material in this chapter are included in the chapter's Creative Commons license, unless indicated otherwise in a credit line to the material. If material is not included in the chapter's Creative Commons license and your intended use is not permitted by statutory regulation or exceeds the permitted use, you will need to obtain permission directly from the copyright holder.

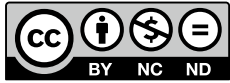

